\title{
Multivariate analysis used as a tool to select snap bean (Phaseolus vulgaris L.) genotypes
}

\author{
Tâmara Rebecca Albuquerque de Oliveira ${ }^{1}{ }^{*}$, Geraldo de Amaral Gravina ${ }^{1}$, Gustavo Hugo Ferreira de \\ Oliveira ${ }^{2}$, Lanusse Cordeiro de Araujo ${ }^{1}$, Kleberson Cordeiro Araújo ${ }^{3}$, Derivaldo Pureza da Cruz ${ }^{1}$, Antônio \\ Teixeira do Amaral Junior ${ }^{1}$, Marcelo Vivas ${ }^{1}$, Rogério Figueiredo Daher ${ }^{1}$
}

${ }^{1}$ Center for Agro-Food Science and Technology, State University of Northern Fluminense, Rio de Janeiro, RJ, 28035200, Brazil

${ }^{2}$ Federal University of Sergipe, Glória, SE, 49100-000, Brazil

${ }^{3}$ Federal Fluminense Institute, Bom Jesus de Itabapoana, RJ, 28060-010, Brazil

\section{* Corresponding author: tamara_rebecca@hotmail.com}

\section{Abstract}

Abstract - Snap bean is a popular and promising vegetable in Southeastern Brazil . The aim of the current study is to use the multivariate analysis as tool to select snap bean genotypes presenting desired agronomic traits. The study followed a randomized block experimental design, with 4 repetitions and 30 genotypes. The principal component and biplot analyses, as well as clustering, were conducted according to the UPGMA method in order to investigate the mean pod weight (MPW), number of seeds per pod (NSP), pod length (PL), pod width (PWi), total pods (MNP), weight of one hundred seeds (W100S), pod yield (PY) and grain yield (GY). The PL, NSP, MPW and W100S presented positive correlation with GY, besides their indication to direct genotype selection. The PWi and TP were efficient for PY selection. The multivariate analyses suggested the selection of lines UENF 7-10-1, UENF 7-12-1 and UENF 7-20-1, which presented good seed yield, as well as of UENF 14-22-3 and UENF 14-23-3, which showed aptitude to production. Lines located in Group II (UENF 14-4-3, UENF 15-6-4, UENF 7-4-1, UENF 7-9-1, UENF 7-7-1, UENF 7-5-1) did not have good performance in the measured traits and could be discarded. Line UENF 1445 "PARENT 19" proved its potential for seed yield, thus it was promising for the development of productive genotypes. Line 14-3-3 presented good aptitude for negatively correlated variables, because it associated good trait with morphology, seed yield, and pod and grain yield morphological traits.

Keywords: Biplot; genetic distance; Phaseolus vulgaris L.

Abbreviations: MPW_pod weight; NSP_number of seeds per pod; PL_pod length; PWi_pod width; MNP_total pods; W100S_weight of one hundred seeds; PY_pod yield; and GY_grain yield.

\section{Introduction}

Snap beans are much appreciated vegetables. According to FAO (2014), their production is estimated to reach approximately 21 million tons worldwide. They are widely consumed and commercialized in Brazil; moreover, their production is distributed in four regions, $25 \%$ of the total production is in Northeastern and Midwestern Brazil, whereas $75 \%$ of it is in the Southeastern and Southern regions of the country (Melo and Vilela, 2008).

Although Brazil ranks sixth among the biggest producing countries, little attention has been given to snap beans breeding. The traits of interest for this crop have been empirically selected (Kurek et al., 2001); in most cases, their selection and maintenance have been conducted by farmers who re-use their own seeds. In addition, lack of information is another problem linked to this crop, because it impairs getting snap bean cultivars adapted to particular regions.

The presence of genetic variability among the used genotypes is of extreme importance for breeding programs. Estimating the genetic distance between genotypes is the best way to predict genetic variability (Hosan et al., 2010); genetic distance estimates and multivariate analyses can help improving selection robustness.

Multivariate analysis techniques are important tools used to select genotypes based on their main traits. The principal component analysis (PCA) is a powerful technique, which stands out among the multivariate ones, since it reduces the set of agronomic traits in the studied genotypes. The technique creates orthogonal axes called principal components, which are linear combinations between the original variables (Leite et al., 2016). Several variables, as well as study genotypes, are simultaneously analyzed in an accurate, robust and integrated analysis (ACP-biplot) using the biplot technique, which derives from the principal component of the matrix (Maia et al., 2016). Thus, although snap beans are appreciated by consumers, its culture is little studied, but the multivariate technique is relevant for its cultivation, in terms of genotype selection. The graphical analysis made through this technique makes it easy to identify the genotypes showing the best performance in the assessed traits; moreover, it allows making a more rigorous 
selection in order to obtain the desirable gains. There are few studies in the literature about the correlation between variables in snap beans, mainly of whom involve a large number of traits to be simultaneously analyzed.

Accordingly, the aim of the current study was to use the multivariate analysis as tool to select snap bean genotypes.

\section{Results and discussion}

\section{Principal component analysis}

According to Silva and Sbrissia (2010) the principal component analysis (PC) enhances data interpretation, since it holds as maximum information as possible within a smaller number of PCs.

The eight traits were represented by three principal components, fact that explains $74.27 \%$ of total data variations (Table 2). Descriptors presenting greater Eigenvectors are those of major relevance for the respective components. Thus, by taking into consideration the weighing of the principal components, it was possible observing that the mean number of pods in PC1 presented the greatest contribution for genotype discrimination. The following traits standing out in PC2 were number of seeds per pod, pod length and mean pod weight. Finally, PC3 stood out for 100 -seed weight, pod yield and grain yield. Pod morphological traits and seed yield were grouped in the first two principal components. The greatest importance in the third component was related to pod and grain yield. Moreira et al. (2009) reported the same results; however, they found that pod yield was the trait showing the lowest relative contribution, fact that was also observed in the current study. Cruz and Regazzi (2001) reported that the character that did not change among the studied genotypes, as well as that have presented correlation to other important traits, can be discarded as selection criterion.

Line and cultivar scores were recorded in order to make it easier selecting the best genotypes for specific traits (Table 3). Accordingly, adapted genotypes were those presenting the highest values in the three columns within the table.

The indicated lines were PC1, UENF 9-3-2, UENF 9-27-2, UENF 14-3-3, UENF 14-6-3, UENF 14-22-3, UENF 14-23-3, UENF 15-8-4 and UENF 15-25-4, in the first column; UENF 73-1, UENF 7-6-1, UENF 7-14-1, UENF 7-28-1, UENF 9-3-2, UENF 9-24-2, UENF 14-3-3, UENF 14-11-3, UENF 14-16-3, UENF 15-7-4 and UENF 15-23-4, in the second; and UENF 1445 "PROGITOR 19", UENF 7-10-1, UENF 7-12-1, UENF 927-2, UENF 14-3-3, UENF 14-11-3 and UENF $14-23-3$ in the third column. Line UENF 14-3-3 was the most stable one for the traits represented by PCs, since it associated good pod morphological traits with seed yield, and with pod and grain yield. Lines UENF 7-12-1 and UENF 14-23-3 and cultivar TOP SEED Blue Line presented the lowest scores in the first, second and third axes, respectively.

Abreu et al. (2004) recommended using parent UENF 1445 in snap bean enhancement because it represented good agronomic attributes, mainly for seed and pod yield. Parent UENF 1445 stood out for the following attributes: 100-seed weight, and pod and grain yield; this outcome corroborated the present results. However, the good quality of this line was not confirmed for the number of seed per pod, wherein it recorded the lowest relative contribution to the second axes (table 3), which features this trait.

\section{Biplot analysis}

The graphical visualization through this methodology allows observing the multivariate relation between variables, as well as selecting genotypes according to the variable they were correlated with. According to Yang et al. (2009), PCs that together explain $60 \%$ of all data variation can be efficient in multivariate genotype correlation and selection studies of graphic representation. Thus, genotype and variable values were plotted in the same graph. Variables presenting vectors with angles shorter than $90^{\circ}$ were positively correlated, whereas those with angles larger than $90^{\circ}$ were negatively correlated; the ones with angle equal to $90^{\circ}$ presented no correlation (Yan and Fregeau-Reid 2008). Variables related to seed yield (grain yield, 100-seed weight and number of seeds per pod) were highly correlated with pod morphological traits (mean pod weight, pod length, pod productivity and pod width) (Figure 2). This result indicated that the higher the value of the pod morphological components, the greater the grain yield. There were redundant traits among the morphological components. Pod width and mean pod weight were not excluded from the experiment, and the use of these variables may be optional in snap bean enhancement programs, since evaluation easiness is a criterion of choice. Abreu et al. (2004) applied the cluster analysis, with and without total pod weight per fraction, and found that this variable can be discarded in further studies involving snap beans. These results diverge from cowpea (Oladejo et al., 2011) and green bean (Singh et al., 2014) evaluations; however, traits related to seed yield were exclusive and each one of them regards significant and considerable information about cultivars and lines in the present study. Similar studies were found by Paramesh et al. (2016), who reported that these results can be interpreted due to angle and size differences resulting from vectors associated with variables in the biplot. The mean number of pods is negatively correlated to the number of seed per pod, pod width and mean pod weight. This result evidences that genotypes presenting the greatest mean number of pods per plant can be more productive and good for genotype selection when the seed yield is the goal, since there is no evidence of linear correlation to this trait; similar results were found by Araújo et al. (2012). Moreover, genotypes located in the upper right quadrant presented good aptitude for negatively correlated traits. Based on the inter-relation between variables within the biplot, it is possible suggesting that the variables 100 -seed weight, mean pod weight or pod width, and number of seeds per pod can be taken into consideration in breeding programs when the development of genotypes with high grain yield is the goal. These results corroborate those in studies that had assessed the correlation between agronomic variables in different bean genotypes (Cabral et al. 2011; Gasin et al. 2015; Santos et al. 2015). Different results were found in common beans and snap beans through cause and effect analyses (Bertini et al., 2010; Ribeiro et al., 2014; Freitas et al., 2016).

\section{UPGMA cluster}

The cophenetic correlation presented $84 \%$ magnitude; thus, indicating consistency in the conducted clustering, which was performed according to the UPGMA method (that formed six groups) (Figure 3 ). The clusters were set with the 
Table 1. Description of the progenies to be selected. Rio de Janeiro, State University of Norte Fluminense, 2015.

\begin{tabular}{lccc}
\hline Genotypes & Identification & Genotypes & Identification \\
\hline 1 & PROGENITOR 19 (UENF 1445) & 16 & UENF 9-3-2 \\
2 & FELTRIN & 17 & UENF 9-24-2 \\
3 & TOP SEED Blue Line & 18 & UENF 9-27-2 \\
4 & UENF 7-3-1 & 19 & UENF 14-3-3 \\
5 & UENF 7-4-1 & 20 & UENF 14-4-3 \\
6 & UENF 7-5-1 & 21 & UENF 14-6-3 \\
7 & UENF 7-6-1 & 22 & UENF 14-11-3 \\
8 & UENF 7-7-1 & 23 & UENF 14-16-3 \\
9 & UENF 7-9-1 & 24 & UENF 14-22-3 \\
10 & UENF 7-1 0-1 & 25 & UENF 14-23-3 \\
11 & UENF 7-12-1 & 26 & UENF 15-6-4 \\
12 & UENF 7-14-1 & 27 & UENF 15-7-4 \\
13 & UENF 7-20-1 & 28 & UENF 15-8-4 \\
14 & UENF 7-28-1 & 29 & UENF 15-23-4 \\
15 & UENF 9-1 -2 & 30 & UENF 15-25-4 \\
\hline
\end{tabular}

Table 2. Correlations between agronomic traits and principal components (PC1 and PC2) of snap bean genotypes. Rio de Janeiro, State University of Norte Fluminense, 2015.

\begin{tabular}{lccc}
\hline \multirow{2}{*}{ Traits } & \multicolumn{3}{c}{ Principal Component } \\
\cline { 2 - 4 } & PC1 & PC2 & PC3 \\
\hline MNP & 3.55 & -0.84 & 0.38 \\
NSP & -4.44 & 1.39 & 0.01 \\
PL & -4.67 & 1.19 & 1.28 \\
Pwi & -0.95 & -3.99 & -3.01 \\
MPW & -3.34 & 0.80 & -2.49 \\
W100S & -4.22 & -0.63 & 0.20 \\
PY & -1.61 & -3.90 & 2.78 \\
GY & -4.82 & -0.96 & 0.24 \\
\hline Var. (\%) & 47.45 & 63.50 & 74.27 \\
\hline
\end{tabular}

Pod length (PL), number of seeds per pod (NSP), mean pod weight (MPW), weight of one hundred seeds (W100S), grain yield (GY), pod yield (PY) and width (PWi); Var.(\%): Accumulated variance explained.

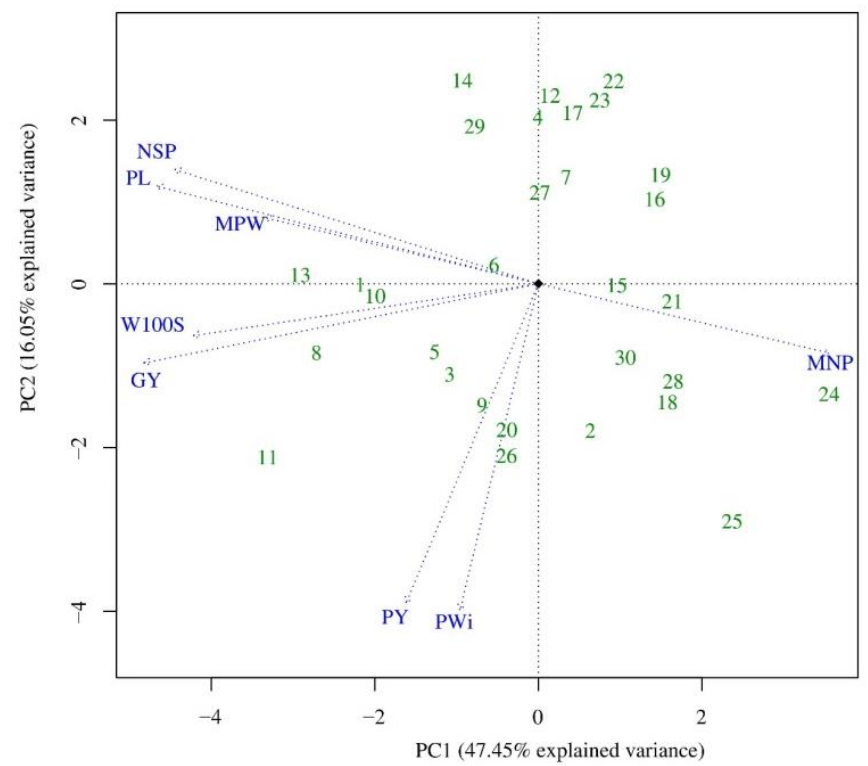

Fig 1. Biplot with variable projections: Pod length (PL), number of seeds per pod (NSP), mean pod weight (MPW), weight of one hundred seeds (W100S), grain yield (GY), pod yield (PY), total pod (MNP) and pod width (PWi) of 30 snap bean lines. Rio de Janeiro, State University of Norte Fluminense, 2015. 


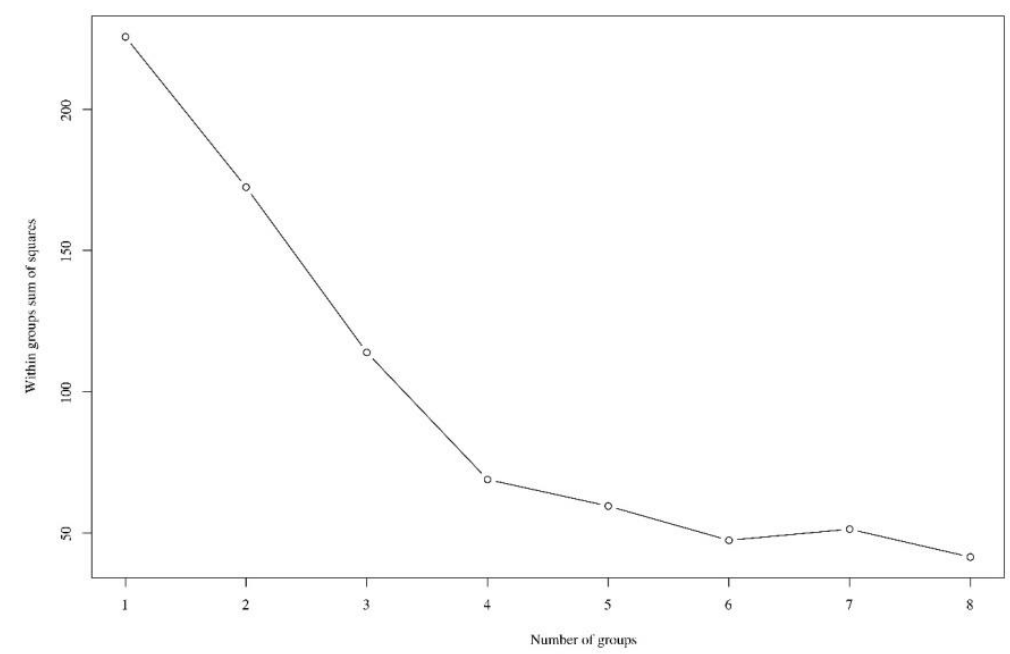

Fig 2. Scree Plot to select the best number of groups based on the sum of squares of 30 snap bean lines within groups. Rio de Janeiro, State University of Norte Fluminense, 2015.

Table 3. Scores of one parent, 2 commercial cultivars and 27 snap bean inbreed lines regarding the three principal components (PC1, PC2 and PC3). Rio de Janeiro, State University of Norte Fluminense. 2017.

\begin{tabular}{|c|c|c|c|c|}
\hline \multirow{2}{*}{ ID } & \multirow{2}{*}{ Genotypes } & \multicolumn{3}{|c|}{ Principal component } \\
\hline & & PC1 & $\mathrm{PC2}$ & PC3 \\
\hline 1 & UENF 1445 & -2.17 & -0.01 & 2.96 \\
\hline 2 & FELTRIN & 0.64 & -1.78 & 1.08 \\
\hline 3 & TOP SEED Blue Line & -1.07 & -1.10 & -2.97 \\
\hline 4 & UENF 7-3-1 & 0.003 & 2.04 & -0.38 \\
\hline 5 & UENF 7-4-1 & -1.26 & -0.83 & -1.23 \\
\hline 6 & UENF 7-5-1 & -0.53 & 0.23 & -2.84 \\
\hline 7 & UENF 7-6-1 & 0.34 & 1.30 & -0.19 \\
\hline 8 & UENF 7-7-1 & -2.70 & -0.84 & -2.44 \\
\hline 9 & UENF 7-9-1 & -0.68 & -1.48 & -1.26 \\
\hline 10 & UENF 7-10-1 & -1.98 & -0.14 & 3.48 \\
\hline 11 & UENF 7-12-1 & -3.29 & -2.11 & 1.15 \\
\hline 12 & UENF 7-14-1 & 0.15 & 2.30 & 0.63 \\
\hline 13 & UENF 7-20-1 & -2.89 & 0.11 & 1.06 \\
\hline 14 & UENF 7-28-1 & -0.91 & 2.48 & -0.68 \\
\hline 15 & UENF 9-1-2 & 0.97 & -0.01 & 0.68 \\
\hline 16 & UENF 9-3-2 & 1.43 & 1.03 & -0.20 \\
\hline 17 & UENF 9-24-2 & 0.43 & 2.09 & -0.80 \\
\hline 18 & UENF 9-27-2 & 1.59 & -1.44 & 1.52 \\
\hline 19 & UENF 14-3-3 & 1.42 & 1.00 & 1.43 \\
\hline 20 & UENF 14-4-3 & -0.37 & -1.78 & -0.61 \\
\hline 21 & UENF 14-6-3 & 1.65 & -0.21 & 0.17 \\
\hline 22 & UENF $14-11-3$ & 0.93 & 2.48 & 2.73 \\
\hline 23 & UENF 14-16-3 & 0.76 & 2.24 & -1.48 \\
\hline 24 & UENF 14-22-3 & 3.57 & -1.34 & -1.59 \\
\hline 25 & UENF 14-23-3 & 2.38 & -2.89 & 1.90 \\
\hline 26 & UENF 15-6-4 & -0.37 & -2.09 & -0.41 \\
\hline 27 & UENF 15-7-4 & 0.03 & 1.12 & 0.25 \\
\hline 28 & UENF 15-8-4 & 1.63 & -1.39 & -0.38 \\
\hline 29 & UENF 15-23-4 & -0.76 & 1.92 & -1.08 \\
\hline 30 & UENF 15-25-4 & 1.07 & -0.89 & -0.50 \\
\hline
\end{tabular}




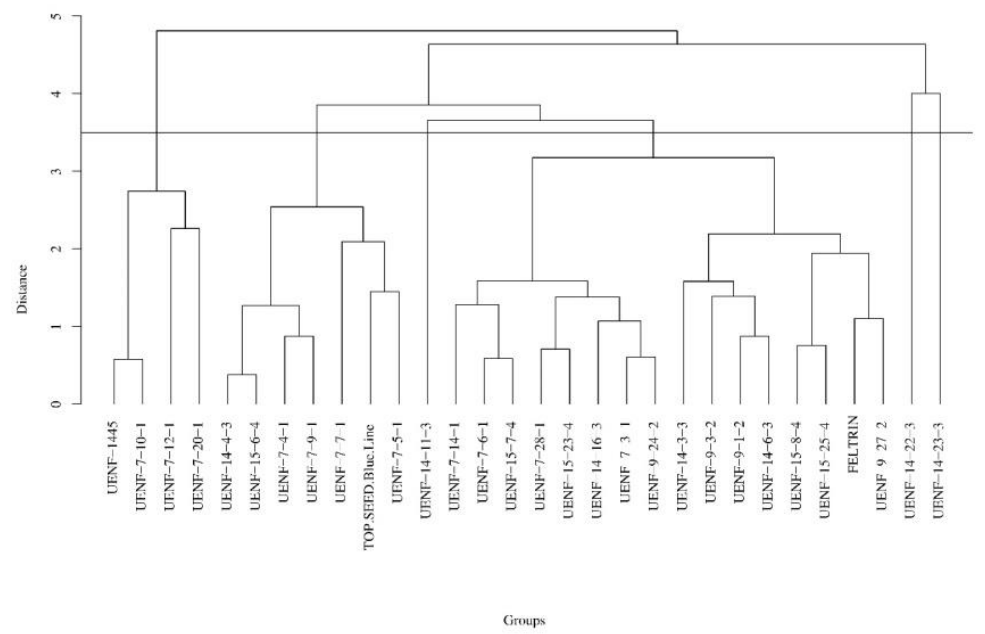

Fig 3. Dendrogram of 30 snap bean lines, based on Mahalanobis distances. Rio de Janeiro, State University of Norte Fluminense, 2015.

aid of the analysis presented in Figure 2; the graph represents cluster formation, fact that minimizes the sum of squares within the cluster. The rate of distances between accessions was represented in axis $X$, whereas the 28 lines and 2 cultivars were represented in axis $Y$ (Figure 2). Group I comprised lines UENF 1445 "Parent 19", UENF 7-10-1, UENF 7-12-1 and UENF 7-20-1, whereas Group II comprised the control (TOP.SEED Blue line), UENF 14-4-3, UENF 15-16-4, UENF 7-4-1, UENF 7-9-1, UENF 7-7-1 and UENF 7-5-1. Group III comprised only one UENF line (UENF 14-11-3), Group IV comprised 15 UENF lines (UENF 7-14-1, UENF 7-6-1, UENF 15-7-4, UENF 7-28-1, UENF 15-23-4, UENF 14-16-3, UENF 73-1, UENF 9-24-2, UENF 14-3-3, UENF 9-3-2, UENF 9-1-2, UENF 14-6-3, UENF 15-8-4, UENF 15-25-4, UENF 9-27-2) and the control (FELTRIN); Groups V and VI comprised one UENF line, UENF 14-22-3 and 14-23-2, respectively. It was observed that lines from the same parents were not located in similar groups. Techniques used in the present study allow confirming variability among the 28 lines in the germplasm bank of UENF; similar results were found by Teixeira et al. (2004). The inclusion of new materials can increase the existing variability and, thus, increase the chance of selecting materials with different aptitudes and yield. The genetic divergence analyses may help breeders to manage crossings between contrasting genotypes. Accordingly, it is possible indicating crossings between promising lines in Group I, which present high aptitude for seed yield component, and the line in Groups V (UENF 1422-3) and VI (UENF 14-23-3). These lines showed the greatest effective contributions to the principal component (mean number of pods), as well as formed isolated groups. Diallel crossings emerge as good instruments for future studies involving these germplasms. Information such as the combinatory capacity of these lines, either in the broad or in the specific sense, may help forming base populations and choosing the lines for specific hybrid combinations.

Thus, the solid initial structure of the snap bean enhancement program can be set in order to assure the obtainment of superior genotypes presenting good performance in grain and pod yield based on promising crossings. Besides, other techniques can be used in further studies involving this germplasm, for instance, the application of molecular instruments. According to Abreu et al. (2004), molecular instruments are relevant for snap bean enhancement programs, mainly when the goal is to compare the recorded phenotypic results.

Materials and methods

\section{Genotypes used in the study and experimental site}

The genetic diversity of the 25 accessions of UENF Germplasm Bank showing indeterminate growth habit was herein featured and investigated. Then, divergent accessions presenting desirable traits were crossbred in order to find diallelic hybrids and to, subsequently, advance the generations and selected productive genotypes of commercial quality in Northern and Northwestern Rio de Janeiro State. Thirty (30) snap bean genotypes were assessed in 2015 at Federal Fluminense Institute (IFF Instituto Federal Fluminense), Bom Jesus de Itabapoana County, Northwestern Rio de Janeiro State (latitude $21^{\circ} 08^{\prime}$ $02^{\prime \prime} \mathrm{S}$, longitude $41^{\circ} 40^{\prime} 47^{\prime \prime} \mathrm{W}$; altitude $88 \mathrm{~m}$ ) (Table 1) in order to advance the generations. The region has tropical climate and mean annual temperature $23^{\circ} \mathrm{C}$.

\section{Adopted Design}

The study followed a randomized block design, with 4 repetitions and 30 treatments; 2 commercial genotypes (Feltrin and Top Seed Blue Line) were assessed as productive genotype control and 1 as parent (UENF 1445). The plot comprised 4 rows $(5 \mathrm{~m}), 1.0 \mathrm{~m}$ spacing between rows and $0.5 \mathrm{~m}$ spacing between plots. Three (3) seeds were sown in each hole. Thinning was performed 10 days after planting, one plant was left per hole, thus totaling 40 plants per plot. The plants were supported with bamboo stakes and wire, 15 days after emergence. The analyses were based on 8 plants located in the middle of the row; the 2 plants in the extremities were kept for seed production. The fertilizations 
followed the soil analysis guidelines. The cultural and phytosanitary treatments followed the recommendations for the culture, according to Filgueira (2008), whereas the irrigation was done through sprinkling.

\section{Analyzed variables}

Data were collected at culture physiological maturity. The herein analyzed variables were Mean pod weight (MPW) mean pod/plant total weight (in grams - g) calibrated through precision scale; Number of seeds per pod (NSP) number of seeds per plant; Pod length (PL) - dry pod measured (in centimeters $-\mathrm{cm}$ ) by using a ruler; Pod width (PWi) - dry pods, in central position, measured (in millimeters - $\mathrm{mm}$ ) by using a digital caliper; Weight of one hundred seeds (W100S) - 100 seeds from a randomly chosen sample weighted on a duly regulated precision scale; Pod yield (PY) - total weight (in grams - g) of pods in each plant measured on a precision scale; Grain yield (GY) - total weight (in grams - g) of grains in each plant, after pod threshing, measured on precision scale.

\section{Statistical analysis}

The principal component analysis (PCA) was used to investigate data collected in the current study. The eigenvalues of all principal components were presented. The eigenvectors were used to better differentiate genotypes in the herein assessed production components. The first two PCs (PC1, PC2) and PC3 presented the greatest variability in the tested parameters and were used for genotype clustering. The biplot was generated based on the genotypes' values; PC1 was used in the horizontal axis, and $P C 2$, in the vertical axis. The effective contribution of genotypes in the first three components were used to generate the distance between genotypes by using the mean Euclidian distance. The Person's correlation between the distance and cophenetic matrices was used to determine cluster cohesion. The analyses applied to the principal component and to the biplot were performed in the $R$ software, whereas the clustering was performed according to the UPGMA.

\section{Conclusion}

The multivariate analyses suggested the selection of lines UENF 7-10-1, UENF 7-12-1 and UENF 7-20-1, which had good aptitude for pod yield. The lines located in Group II (UENF 14-4-3, UENF 15-6-4, UENF 7-4-1, UENF 7-9-1, UENF 7-7-1, UENF 7-5-1) did not present good performance in the herein assessed traits and could be discarded.

Line UENF 1445 "PARENT 19" confirmed it potential for seed yield, since it was a promising parent for the development of productive genotypes. The line UENF 14-3-3 presented good aptitude for negatively correlation variables, because it associated good pod morphology traits with seed yield, and with pod and grain yield.

\section{Acknowledgements}

Thanks to CAPES and CNPq for the granted scholarship.

\section{References}

Teixeira $A B$, Amaral Júnior AT, Rodrigues R, Pereira TNS, Bressan-Smith R E (2004) Genetic divergence in snap-bean (Phaseolus vulgaris L.) evaluated by different methodologies. Crop Breed Appl Biot. 4: 57-62.

Araújo LC, Gravina GA, Marinho CD, Almeida SNC, Daher RF, Amaral Júnior AT (2012) Contribution of components of production on snap bean yield. Crop Breed. Appl Biot. 12: 206-210.

Bertini CHCM, Almeida WS, Silva APM, Silva JWL, Teófilo EM (2010) Análise multivariada e índice de seleção na identificação de genótipos superiores de feijão-caupi. Acta Sci Agron. 32: 613-619.

Cabral PDS, Soares TCB, Lima ABP, Soares YJB, Silva JA (2011) Análise de trilha do rendimento de grãos de feijoeiro (Phaseolus vulgaris L.) e seus componentes. Rev Ciênc Agron. 42: 132-138.

Cruz CD, Regazzi AJ (2001) Modelos biométricos aplicados ao melhoramento genético. 2rd edn. Viçosa, Minas Gerais.

FAO - Food and Agriculture Organization (2016) Statisitical databases: Agriculture. Available at: <http:www.//apps.fao.org>. Access in: 10 November 2016.

Filgueira FAR (2003) Novo manual de olericultura: agrotecnologia moderna na produção de hortaliças. Viçosa: Minas Gerais.

Freitas TGG, Silva PSL, Dovale JC, Silva EM (2016) Rendimento de grãos verdes e análise de trilha em variedades tradicionais de feijão-caupi. Rev Caatinga. 29: 866-877.

Abreu FB, Leal NR, Rodrigues R, Amaral Júnior AT, Silva DJH (2004) Divergência genética entre acessos de feijão-devagem de hábito de crescimento indeterminado. Hort Bras. 22: 547-552.

Gasim S, Hamad SAA, Abdelmula A, Ahmed IAM (2015) Yield and quality attributes of faba bean inbred lines grown under marginal environmental conditions of Sudan. Crit Rev Food Sci Nutr. 3: 539-547.

Hosan SM, Iftekharudduala KM, Ahmed MDNU, Mia S (2010) Genetic divergence in landraces of Bangladesh rice (Oryza sativa L.). The Agriculturists. 8: 28-34.

Kurek AJ, Carvalho FIF, Assmann IC, Cruz PJ (2001) Capacidade combinatória como critério de eficiência na seleção de genitores em feijoeiro. Pesq Agrop Bras. 36: 645-651.

Leite WS, Pavan BE, Alcântara Neto F, Matos Filho CHA, Feitosa FS, Oliveira CB (2016) Multivariate exploratory approach and influence of six agronomic traits on soybean genotypes selection. Nativa. 4: 206-210.

Maia MCC, Araújo LB, Dias CTS, Oliveira LC, Vasconcelos FL F, Carvalho Júnior JEV, Simeão M, Bastos YGM (2016) Selection of mango rosa genotypes in a breeding population using the multivariate-biplot method. Ciênc Rural. 46: 1689-1694.

Melo PC, Vilela NJ (2008) A importância da Cadeia Produtiva Brasileira de Hortaliças. Available at: $<$ http://www.abhorticultura.com.br/downloads/cadeia_pr odutiva.pdf>. Access in: 15 November 2016.

Moreira RMP, Ferreira JM, Takahashi LSA, Vasconcelos MEC, Geus LC, Botti L (2008) Potencial agronômico e divergência genética entre genótipos de feijão-vagem de crescimento determinado. Cien Agrar. 30: 1051-1060. 
Oladejo AS, Akinwale RO, Obisesan IO (2011) Interrelationships between grain yield and other physiological traits of cowpea cultivars. Afr Crop Sci. 19: 189-200.

Paramesh $M$, Reddy DM, Shanthi Priya $M$, Sumathi $P$, Sudhakar P and Reddy KHP (2016) GT biplot analysis for yield and drought related traits in mung bean (Vigna radiata L. Wilczek). Electronic Journal of Plant Breeding. 7: 538-543

Ribeiro ND, Domingues LS, Zemolin AEM (2014) Avaliação dos componentes da produtividade de grãos em feijão de grãos especiais. Científica. 42: 178-186.

Singh C M, Mishra S B, Pandey A (2014) Pattern of agromorphological trait relationship and genetic divergence in greengram [Vigna radiata (L.) Wilczek]. Electronic Journal Plant Breed. 5: 97-106.
Santos A, Braga DC, Correa AM, Melo CLP, Silva JAS, Lima AR $S$, Rodrigues EV (2015) Escolha de genitores de feijãocomum baseado na divergência genética. Rev Agrarian. 8: 235-245.

Silva SC, Sbrissia AF (2010) Análise de components principais entre características morfogênicas e estruturais em capimmarandu sob lotação contínua. Ciênc Rural. 40: 690-693.

Yang RC, Crossa J, Cornelius PL, Burgueño J (2009) Biplot analysis of genotype $x$ environment interaction: Proceed with caution. Crop Sci. 49: 1564-1576.

Yan W, Fregeau-Reid JA (2008) Breeding line selection based on multiple traits. Crop Sci. 48: 417-423. 